with computer software. "The computer can't do it all for you," she says. "It's still just a tool like pencil and paper."

Keynote speaker Warren D. Allmon is not an artist, but an invertebrate palaeontologist. Scientific illustrators are "especially important in palaeontology, which is a mixture of science, inspired guesses, and artistic creativity to form a picture of what animals may have once looked like". The images can also help kids to think about how scientists do palaeontology, he explains. Reconstructing ancient worlds will be the focus of another keynote speaker, James Gurney, author and illustrator of Dinotopia: A Land Apart From Time (HarperCollins, 1992) and the artist behind the World of Dinosaurs series of US postage stamps.

Science illustrators claim that the origin of their craft dates back to prehistoric cave drawings. Medieval physicians, alchemists, naturalists and early scientists - including Newton and Galileo - used etchings and engravings to supplement their manuscripts. One of the best examples is Robert Hooke's Micrographia. Published in 1665, it introduced readers to the microscopic world through its detailed drawings.

"Historically, most illustrators have worked in isolation," adds Halpert. "The formation of the guild helped us learn what others were doing. What many think of as disparate vocations [science and art] have always been two sides of the coin."

Nick Thomas is an associate professor of chemistry at Auburn University Montgomery,

Alabama 36124-4023, USA.

\title{
Climate comedy falls flat
}

\section{Sizzle}

Premieres 19 July at Outfest Film Festival, California; screens on 26 July at Woods Hole Film Festival, Massachusetts. Showing at US universities thereafter.

After watching Al Gore's straight-faced presentation in the 2006 film An Inconvenient Truth, director Randy Olson turned to humour to tackle the issue of climate change. "I really liked it," he says of Gore's documentary in the opening to Sizzle, Olson's new film that premieres in Hollywood on 19 July, "but I kept thinking 'where are all the scientists?"

Part documentary, part mockumentary, Sizzle follows Olson as he interviews scientists and sceptics from around the United States with the help of a crew of thinly drawn comedic characters. Director of the well-received 2006 documentary on intelligent design, Flock of Dodos, Olson is no stranger to portraying society's complex response to science. Sadly, Sizzle's mix of styles confuses his message.

The interviewees, including researchers such as Gerald Meehl at the National Center for Atmospheric Research in Colorado and Richard Somerville at the Scripps Institution of Oceanography in California, look as if they think they are being interviewed for a straight documentary. Then Olson's cameraman, a climate-change sceptic played by comedian Alex Thomas in a solid and funny performance, butts in with his own contribution, a running gag that the film turns into a point about scientific communication: when you ask dumb questions in everyday language, scientists suddenly start talking like 'normal' people.

Olson argues that data alone fail to convince people to care about climate change. What succeeds is anecdote and emotion. Indeed, the film contains very little data. The interviews are edited down to mere stubs, with no explanation of what climate change is or why we should laugh at the sceptics. Perhaps Olson assumes his audience has previous knowledge.

Olson heads to New Orleans in search of compelling anecdotes. With the caveat that the relationship between climate change and hurricanes is still being worked out, he argues like many before him, including Gore, that Hurricane Katrina is a window into a climate-changed world - even the richest nation on Earth disintegrates into anarchy in the face of terrible natural disasters. But once he gets there, Olson wanders off-topic, preferring to criticize the federal response to the hurricane.

The film is good in places and provides insights into the social response to climate change. But some of the mockumentary's jokes, meant to keep us watching, are rather stale: an elderly white woman - Olson's mother - goes out on the town with the young black camera crew, and the gay film producers throw several colourful hissy fits.

Ultimately, one is left wondering what the film aims to do. Does it argue that climate change is real, or discuss how we might convince people that it is? At the end of the film, Olson heads off to the editing studio to make a coherent story out of his footage. If only we had got to see that version.

Emma Marris is a correspondent for Nature.

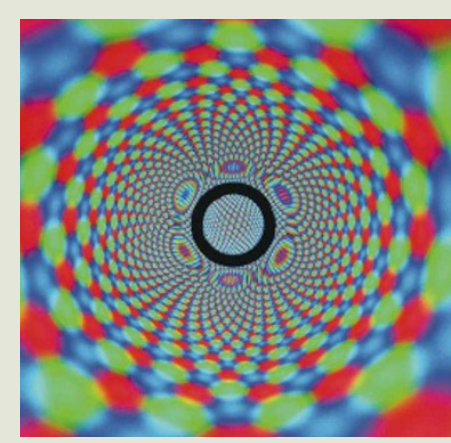

AND THE WINNER IS...

The winners of the Niche Prize, a competition held by the Royal Institution of Great Britain in partnership with Nature, have been announced. The winning works will be displayed in two wall niches on the ground floor of the institution in London, which reopens to the public in August. The Malaria Lifecycle (detail, below), by Australian visual designer Drew Berry, is a scientifically accurate animation of the malaria parasite invading a human host. Faraday's Magnetoscape (above) by Ken Skeldon, a research fellow at the University of Glasgow, UK, allows viewers to generate colour patterns by passing a magnet near the screen of a cathode-ray-style computer monitor, celebrating Michael Faraday's discovery of electromagnetic induction at the Royal Institution some 180 years ago.
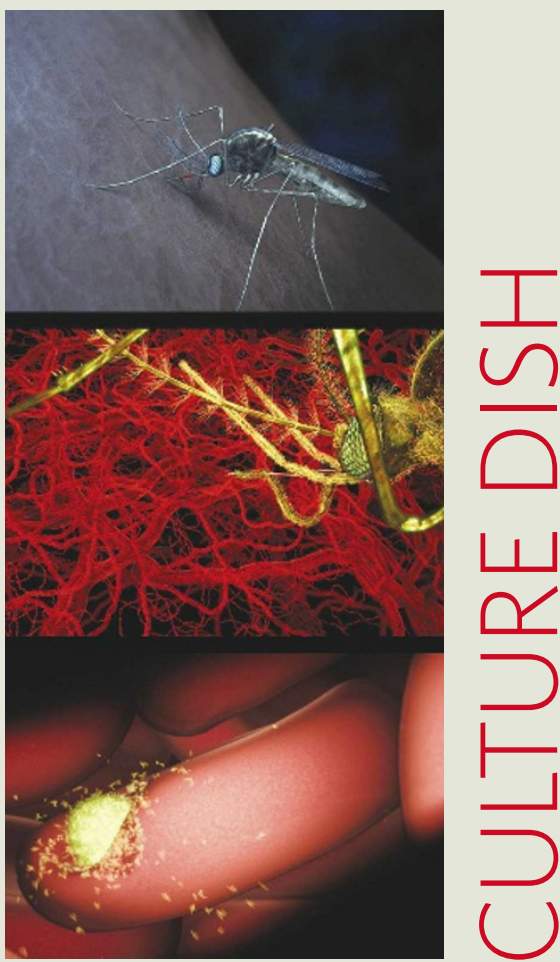